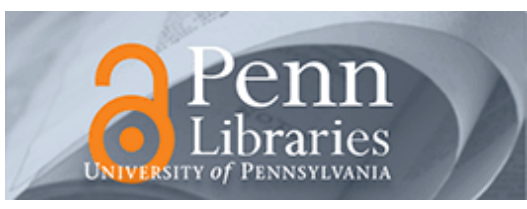

University of Pennsylvania ScholarlyCommons

Wharton Pension Research Council Working

Papers

Wharton Pension Research Council

$8-1-2010$

\title{
What's on the Menu? Included versus Excluded Investment Funds for Singapore's Central Provident Fund Investors
}

Benedict SK Koh

Singapore Management University, skkoh@smu.edu.sg

Olivia S. Mitchell

The Wharton School, University of Pennsylvania, mitchelo@wharton.upenn.edu

Follow this and additional works at: https://repository.upenn.edu/prc_papers

Part of the Economics Commons

Koh, Benedict SK and Mitchell, Olivia S., "What's on the Menu? Included versus Excluded Investment Funds for Singapore's Central Provident Fund Investors" (2010). Wharton Pension Research Council Working Papers. 197.

https://repository.upenn.edu/prc_papers/197

This paper is posted at ScholarlyCommons. https://repository.upenn.edu/prc_papers/197

For more information, please contact repository@pobox.upenn.edu. 


\section{What's on the Menu? Included versus Excluded Investment Funds for Singapore's Central Provident Fund Investors}

\section{Keywords}

Pension, retirement, investment, portfolio, mutual fund, investment choice, stock selection, market timing, plan risk and return

\section{Disciplines}

Economics 


\title{
What's on the Menu? \\ Included versus Excluded Investment Funds for Singapore's Central Provident Fund Investors
}

\author{
Benedict S. K. Koh and Olivia S. Mitchell
}

August 2010

\author{
PRC WP 2010-12 \\ Pension Research Council Working Paper \\ Pension Research Council \\ The Wharton School, University of Pennsylvania \\ 3620 Locust Walk, 3000 SH-DH \\ Philadelphia, PA 19104-6302
}

Tel: 215.898.7620 Fax: 215.898.0310

Email:prc@wharton.upenn.edu

http://prc.wharton.upenn.edu/prc/prc.html

Koh is Professor of Finance at the Singapore Management University and Mitchell is International Foundation of Employee Benefit Plans Professor of Insurance and Risk Management and Executive Director of the Pension Research Council at the Wharton School, University of Pennsylvania, and a Research Associate of the NBER. We acknowledge research assistance from Joelle Fong and Jane He. All opinions are solely those of the authors who acknowledge research support from the Wharton-SMU Research Center at Singapore Management University, the Pension Research Council/Boettner Center at The Wharton School of the University of Pennsylvania, and the Centre for Silver Security of the Singapore Management University. (C) 2010 Koh and Mitchell. All rights reserved. 


\title{
What's on the Menu? \\ Included versus Excluded Investment Funds for Singapore's Central Provident Fund Investors
}

\begin{abstract}
As one of the oldest and largest national mandatory defined contribution pension systems, Singapore's Central Provident Fund (CPF) permits employees to invest their retirement accumulations in a variety of investment instruments rather than leaving them in a governmentmanaged investment fund. Many plan participants avail themselves of this opportunity, selecting from a menu of more than two hundred "included" funds that satisfy specific admission criteria set by the CPF Board. Nevertheless, many other funds are excluded from the list of eligible retirement system investments. This paper shows that the "included/non-included" screening criteria have been effective, in that included fund managers earned higher average returns, demonstrated better stock-picking, and displayed better market-timing skills, than their excluded fund counterparts. In addition, the included funds exhibited stronger persistence in performance, though they offered marginally lower diversification benefits to plan participants.
\end{abstract}

Keywords: pension, retirement, investment, portfolio, mutual fund, investment choice, stock selection, market timing, plan risk and return

\author{
Benedict S. K. Koh \\ Professor of Finance \\ Singapore Management University \\ 50 Stamford Road, \#04-01 \\ Singapore 178899 \\ T: 65-6828-0716・F: 65-6828-0777 \\ Email: skkoh@smu.edu.sg \\ Olivia S. Mitchell \\ International Professor of Employee Benefit Plans \\ Professor of Insurance and Risk Management \\ Director, Pension Research Council \\ Boettner Center for Pensions \& Retirement Research \\ The Wharton School, 3620 Locust Walk, St 3000 SHDH \\ Philadelphia, PA 19104-6320 \\ T: 215-898-0424 • F: 215-898-0310 \\ Email: mitchelo@wharton.upenn.edu
}




\section{What's on the Menu? \\ Included versus Excluded Investment Funds \\ for Singapore's Central Provident Fund Investors}

In most defined contribution (DC) plans, workers have the responsibility to accumulate sufficient saving to finance their own retirement needs. How much wealth they accumulate then depends on the quantum saved over their working lives, as well as the savers' own investment choices, often hampered by financial illiteracy (Lusardi and Mitchell 2007). This paper investigates how one of the world's largest and oldest national mandatory defined contribution systems, Singapore’s Central Provident Fund (CPF), has shaped the environment in which its participants make investment decisions and what outcomes have resulted as a consequence of restricting the menu from which participants can choose. Our findings have implications not only for Singapore, but also for other national funded pension schemes that permit participants to opt-out of a centrally-managed pool and select their own fund managers, including Australia.

Founded in 1955, the Central Provident Fund, Singapore’s mandatory retirement saving scheme, has more than 3 million members (Low and Aw, 1997, 2004). Initially the fund Board exclusively managed workers' assets for them, but from 1986 onwards, participants have been permitted to invest a portion of their retirement saving in professionally-managed funds such as unit trusts (mutual funds) and investment-linked insurance products (ILPs) that they elect themselves, as well as other investment instruments (Koh et al. 2007). In all cases these funds must be managed by private-sector professional fund managers, and while the list of options is long, it is not unlimited, as the set of admitted instruments termed "CPF-included" funds must satisfy specific criteria set out by the institution's governing Board. In what follows, we assess whether the included/non-included distinction has been useful to plan participants as a measure 
of performance. Specifically, we ask whether the "CPF-included” funds included on the menu outperformed the excluded funds when measured against standard performance benchmarks.

This question is of interest for several reasons. First, prior research confirms that average investors face difficulties in making investment decisions due to investment inertia, naive portfolio diversification, excessive reliance on conservative investment options, and financial illiteracy regarding basic investment concepts (Mitchell et al. 2007). This raises doubt as to how plan participants can effectively sieve through the menu of complex financial instruments made available to them, and in turn this highlights a potential role for additional government oversight. Second, the track record of participants who utilized the CPF Investment Scheme (CPFIS) in Singapore was poor over the period 2004-07, when half (47 percent) of plan participants incurred losses and only one-fifth (22 percent) did better than what they could have by leaving their money in the government-managed fund. Third, participants have increasingly delegated their retirement portfolio investment decisions to professional fund managers: CPF-included funds constituted just 16 percent (or $\$ 0.5$ billion) of the unit trust industry’s assets under management in 1997, which surged to two-thirds by 2007 (67 percent or \$26 billion; see MAS 2007). ${ }^{1}$ In view of participants' rising reliance on the government “included” list, we argue that it is sensible to ask whether these unit trusts did at least as well as those excluded from the list.

In what follows, we first briefly review the literature on performance benchmarks used to evaluate professionally-managed investment funds, and then describe the Singapore's CPF Investment Scheme and its structure. This is followed by an analysis of the performance of “CPF-included” unit trusts compared to those excluded from the investment scheme. Specifically, we investigate their aggregate performance statistics, return and risk profiles, degree of 
diversification, stock selection and market timing abilities of funds as well as persistence of performance.

\section{Measuring Fund Performance}

Much of the literature on fund performance has judged manager stock selection skill using fund alphas. Early US mutual fund studies by Jensen (1968) and Sharpe (1966) showed that fund managers generally did not outperform their benchmarks and hence did not exhibit stock selection skill; more recent work by Malkiel (1995) and Gruber (1996) has corroborated this conclusion. Though mutual funds are not generally found to report positive alphas, studies by Grinblatt and Titman (1992) and Hendricks et al. (1993) did report evidence of persistence in mutual fund performance over shorter horizons of up to five years. Thereafter, further investigation by Malkiel (1995) revealed that much of the persistence in performance was restricted to the 1970s and disappeared in the 1980s. Carhart (1997) showed that persistence in U.S. mutual fund performance could be explained by common factors in stock returns and investment expenses. In summary, the literature on US mutual funds has generally not been able to confirm long-term abnormal positive performance by professional fund managers.

Another way researchers have sought evidence of above-average fund manager performance involves examining their market timing ability. Here U.S. evidence on this performance dimension is mixed (Treynor and Mazuy 1966; Chang and Lewellen 1984; Henriksson 1984; Lehmann and Modest 1987; Cumby and Glen 1990; see also Wagner, Shellans and Paul 1992; Brocanto and Chandy 1994; and Ferson and Schadt 1996). When non-stationary systematic risk levels in portfolios that consequently affect mutual fund performance is 
considered, some researchers have found some confirmation of significant timing ability among fund managers (Pfleiderer and Bhattacharya, 1993; Kon and Jen 1979; Miller and Gressis 1980). As for Singapore's unit trusts, Koh et al. (2007) noted that only relatively few (16\%) of CPF participants hold assets outside the government-run fund. Tse and Chia (1997) studied the performance of 36 equity unit trusts which had invested primarily in the Singapore and Asian financial markets (including those outside the CPFIS list) over the period 1990-99. These fund managers appeared not to possess stock selection or market-timing skills, and their performance rankings across years were inconsistent. Nevertheless that study showed that unit trusts provided diversification benefits and higher risk-adjusted returns than the risk-free rate. A more recent study by Chia, Chua, and Tsui (2007) focused on the performance of 87 CPFIS-included unit trusts or about one-third of the 231 funds available over the period 1992-2006. That paper found mixed evidence of stock picking skill, and no evidence of market-timing skill, among the set of included fund managers. In addition, fund manager performance was inconsistent over the period. In what follows, we offer a more comprehensive analysis of the risk-return characteristics of CPFIS-included versus excluded unit trusts available to CPF investors, for two decades ending in December 2001 and 2007. Our dataset used comes from Morningstar Research Private Limited $^{2}$ ("Morningstar") which allows us to evaluate the performance of a wide range of both included and excluded funds on the CPF list. Besides equity-based funds, our study also analyzes balanced and income funds. Accordingly we provide a more comprehensive evaluation of unit trusts than previous studies. 


\section{Singapore’s Central Provident Fund Investment Scheme}

The CPF system is a mandatory defined contribution plan that receives a portion of employees’ monthly wages up to a ceiling amount. Contribution rates and caps have fluctuated over time, but the current rates have held steady at between 8.5 to 34.5 percent of monthly salary depending on the employee’s age, and a ceiling monthly salary cap of \$\$4,500 (approximately US\$3,333).

When the system was first established, the Board centrally directed all investible funds and paid a fixed and government-set return on the assets. Today participants' monthly contributions go into the CPF Ordinary Account (CPF-OA) that pays a 2.5\% risk-free rate on money defaulted into it, and the CPF Special Account (CPF-SA) which pays 4\% on balances. ${ }^{3}$ Alternatively, under the CPF Investment Scheme launched in 1986, participants may invest their accumulations in any of a list of "included" instruments; the menu of instruments offered differs for the Ordinary and the Special Accounts (see Table 1). For example, members may invest their CPF-OA funds in fixed deposits, corporate bonds, property funds, equities traded on the Singapore stock exchange, bonds guaranteed by the Singapore government, annuities and endowments, ILPs, unit trusts, exchange traded funds (ETFs), fund management accounts, gold, Singapore Government Treasury Bills and Gold ETFs. Since the SA funds are designated for retirement, there is a narrower set of permitted investment instruments; this list includes fixed deposits, Singapore Government bonds, Statutory Board bonds and bonds guaranteed by Singapore Government, annuities, endowment insurance policies and selected InvestmentLinked Insurance products, unit trusts and exchange-traded funds classified under the lowest three risk categories classified by CPF.

\section{Table 1 here}




\section{Growth of Unit Trusts under the CPFIS.}

Similar to mutual funds, unit trusts in Singapore are investment vehicles that pool money from numerous individuals to invest in a portfolio of securities such as shares, bonds, or money market instruments. Unit trusts are attractive to investors because they offer diversification benefits and market liquidity, as well as access to the services of professional fund managers. There were 349 Collective Investment Schemes (CIS) in 2007 of which 162 were included in the CPF Investment Scheme. The dollar value of funds contributed by CPF-included CIS was 67 percent (or $\$ 26$ billion) of total CIS assets in 2007, a big jump from the 16 percent (or $\$ 0.5$ billion) in 1997.

\section{Admission Criteria of CPF Investment Scheme}

Not all unit trusts are included in the CPF Investment Scheme menu; rather, the CPF Board has announced specific criteria to screen investment products. As outlined in Table 2, new funds applying for admission must be evaluated based on factors including the fund's investment philosophy, the backgrounds of key decision-makers, the appropriateness and quality of its research and analysis, its portfolio construction and implementation, and its past performance. The Board also seeks to boost the included funds' performance by requiring that new funds must be in the top 25th percentile of their global peer groups and have a track record of at least three years. In addition, admitted funds must levy sales charges of less than three percent, and expense ratios must not exceed the median of the peer group. Funds not meeting these criteria may not accept new CPF funds from plan participants.

Table 2 here 
Rather than screening each of the funds by itself, the Board has outsourced this task to Morningstar, to evaluate whether unit trusts seeking admission into the CPFIS list meet all admission criteria. Hitherto the Board has not expunged any already-included funds for having high expense ratios or front-end loads, but it has prevented them from taking in new CPF investments from plan participants if their expense ratios or sales charges fail to meet these criteria. As a result, existing funds with poor performance can remain in the CPF Investment Scheme indefinitely. On the other hand, a fund that undergoes major changes in its organizational structure, fund structure, or management teams may be subject to review and reevaluation, and the Board could weed out an underperforming fund if it failed to meet the admission criteria during the re-evaluation. Such funds would then need to inform the CPFIS investors in writing and offer them three options: holding on to the units bought, redeeming them, or switching their units for free into other CPFIS funds meeting the criteria.

\section{An Analysis of Fund Performance: On and Off the List}

To investigate empirically whether existing policy has effectively shut out underperforming funds with the screening criteria, we undertake an empirical examination to determine how the CPF "included" funds compare to those not on the list. The latter might be excluded either because they did not meet admission criteria, or they may have voluntarily elected not to participate. The model uses the time series of fund returns having a track record of at least ten years ending December 2001 corresponding to a bust period, and a second ten-year period ending December 2007, which coincided with a bull phase in the stock market. The dataset was obtained from Morningstar Asia which provided monthly price observations at month-end for unit trusts on the Singaporean financial market. We utilize a reinvested income price series which assumes 
that dividend distributions are reinvested. These fund returns are then compared to individual fund benchmark returns specified by the unit trust as well as the three-month Treasury bill rate and the CPF-OA rate (the CPF default interest rate).

\section{Aggregate Performance of CPFIS Unit Trusts}

Like stocks, unit trust values are volatile and fluctuate in tandem with the swings of the stock market. Consequently, holders of unit trusts are not immune against losses in the short run. As a rule, unit trusts are best seen as long-term investments unsuited for short-term speculation; if people hold unit trust investments over the long-term, they will anticipate being able to beat the riskfree rate through capital appreciation and reinvestment of dividends. We test this hypothesis by comparing the performance of CPF-included and excluded unit trusts against the three-month T-bill rate, the CPF-OA rate, and the funds' designated benchmark index. When investors take risk by investing in unit trusts, they expect to earn a return higher than Treasury rates. And since investors can simply leave their saving in the default government-managed account paying the CPF-OA rate, this is also a reasonable yardstick against which to compare unit trust returns. Given that fund managers are full-time professionals with investment skills, they are expected to beat passive benchmark indices.

Table 3 reports summary statistics on the performance of included and excluded unit trusts in the Singaporean marketplace, for two ten-year periods. Both classes of unit trusts reported average returns that exceeded the CPF-OA rate and three-month T-bill rate, which implies that investors who invested their retirement saving in unit trusts did better than those who left their money in the CPF-default accounts. The average return of CPFIS-included unit trusts was 7.96 percent for the ten-year period ending 12/01, and 10.27 percent for the decade ending $12 / 07$. These 
returns are both much higher than the 6.36 and 7.32 percent turned in by the excluded unit trusts for the same periods. A difference of means test was applied and our results show that the mean return of the included funds for period ending December 2007 was significantly higher than that of excluded funds at the $1 \%$ significance level. Accordingly, the funds included on the list outperformed those excluded from the list, in both the bull and bear markets examined.

Table 3 here

Results also show that the performance of unit trusts did vary according to underlying stock market conditions. That is, the unit trusts performed better during the bull market (the decade ending 12/07) than during the previous decade’s bear market (ending 12/01). And we can also conclude that the included unit trusts performed significantly better than those not on the list, particularly during the bear market. Approximately 82 percent of the CPFIS-included funds beat the CPF-OA rate and the T-bill rate, but only 62 percent of the excluded funds did so. In addition, 88 percent of the included funds outperformed their benchmark over the same period, versus only 56 percent of the excluded funds. On the other hand, during the bull market ending 12/07, both sets of funds performed comparably although more included funds beat their benchmarks than did the excluded set.

\section{Comparison of Unit Trust Risk-Return Profiles}

Investors are often advised by financial planners to choose funds that match their preferred risk profiles, where the pools are broadly classified as equity, income, or balanced funds. Equity funds offer higher expected returns and higher risk, since they invest in growth stocks with a high potential for capital appreciation but pay relatively low dividends. Equity funds are therefore usually deemed most suitable for younger investors comfortable with assuming risk. Income funds, 
on the other hand, offer low expected returns by assuming low risk as they usually invest in bonds, money market instruments, and fixed deposits. Most advisers deem these more suitable for retirees or the very risk averse. And balanced funds offer investors moderate capital growth and income at moderate risk, perhaps most suitable for investors with average risk preferences.

Next we seek to investigate whether the unit trusts in our sample positioned their funds according to the risk and return profiles outlined in their prospectuses. We measure the unit trust performance by their average return and average excess return, and their risks by betas or standard deviations of returns. Table 4 reports results for the equity, balanced, and income funds in our sample, where we see that the funds generally provided realized returns and risk consistent with their prospectus profiles. In the bear market, the decade ending 12/07, the included equity funds earned the highest average return (11.19 percent) followed by balanced (7.74 percent) and income funds (3.59 percent). Equity funds also had the highest risk with a standard deviation of 23.44 percent, exceeding that of balanced (15.89 percent) and income funds (2.62 percent). The excluded funds turned in similar results with equity funds earning the highest return and highest risk, and income funds earning the lowest return at the lowest risk. During the bull market, results are less clear. Here balanced funds reported the highest return (9.26 percent) as well as the highest risk levels (25.08 percent). By contrast, the return-risk profile of equity and income funds conformed to expectations.

Table 4 here

\section{Risk Diversification Profiles}

One reason that unit trusts attract the small investor is that they offer risk diversification otherwise unattainable for those having only meager assets to invest in the market. In practice we 
measure risk diversification by the R-square statistic from a regression of excess fund returns on the excess returns of the benchmark index in equation 1 :

$$
\mathrm{R}_{\mathrm{jt}}-\mathrm{R}_{\mathrm{ft}}=\alpha_{\mathrm{j}}+\beta_{\mathrm{j}}\left(\mathrm{R}_{\mathrm{mt}}-\mathrm{R}_{\mathrm{ft}}\right)+\varepsilon_{\mathrm{jt}}
$$

Panel A of Table 5 reports the R-square statistic on equity and balanced funds for both our sample periods (income funds are excluded as fund managers do not try to diversify across asset classes and industries). The results show that both the included and excluded funds are relatively well diversified: average R-squares of equity funds range from 0.71 to 0.83 , while for balanced funds the figures range from 0.71 to 0.82 . These results imply that over 71 percent of the variation in equity and balanced fund returns can be explained by their benchmark indices, confirming that unit trusts have successfully helped investors diversify their portfolio risk. The results also show that excluded unit trusts are marginally more diversified than the included set. A possible explanation for this result is that fund managers in the included list deliberately assume more idiosyncratic risk seeking to beat the market. Our results in the next section seem to confirm this conclusion, since fund managers of included funds also report more positive abnormal returns.

Table 5 here

\section{Stock Selection Skill}

Investors may be attracted to unit trusts as they can tap professional fund manager's expertise to help them earn higher risk-adjusted returns than what they could achieve on their own. Since the professional managers monitor the market on a full-time basis, they can be expected to exhibit stock selection skill, or the ability to pick under-valued stocks for inclusion in a portfolio. The conventional way to gauge stock selection skill uses Jensen's alpha, which refers to the intercept term $\alpha_{j}$ in the excess return equation (1) above. Fund managers who possess superior 
stock selection skills should report a positive alpha, while those with inferior skills will have a negative one.

Panel B of Table 5 reports the Jensen's alphas for equity and balanced funds for the two decade-long periods under study. Here we see that the average alpha earned by included funds is positive for all holding periods, and it ranges from 0.07 to 0.62 percent. By contrast, excluded funds earned much smaller alphas, ranging from -0.01 to 0.1 percent. A difference of means test found that the mean alpha of included funds was larger than that of excluded funds at the 1 percent significance level. In addition, more included funds had significantly positive alphas than the excluded funds: that is, 22.5 percent of the included equity funds had significantly positive alphas versus only 11.43 percent of the excluded equity funds in the decade of the bear market.

\section{Market Timing Ability}

In addition to stock selection, fund managers can use market timing to outperform their benchmark indices. For instance, a fund manager with market timing skill can increase his holdings of risky assets or the risk level of his fund when the market is rising, perhaps by overweighting stocks and underweighting fixed-income securities. Conversely, in a falling market, a superior market timer would underweight stocks and overweight fixed-income securities. The standard way to measure market timing uses the gamma term $\gamma_{\mathrm{j}}$ in a quadratic regression suggested by Treynor and Mazuy (1966):

$$
\mathrm{R}_{\mathrm{jt}}-\mathrm{R}_{\mathrm{ft}}=\alpha_{\mathrm{j}}+\beta_{\mathrm{j}}\left(\mathrm{R}_{\mathrm{mt}}-\mathrm{R}_{\mathrm{ft}}\right)+\gamma_{\mathrm{j}}\left(\mathrm{R}_{\mathrm{mt}}-\mathrm{R}_{\mathrm{ft}}\right)^{2}+\varepsilon_{\mathrm{jt}}
$$

Here a positive $\gamma_{j}$ indicates that the manager is a superior market timer, increasing the weighting of risky securities in a market upturn and decreasing the weighting in a market downturn. 
Results in Panel C of Table 5 show that the average gammas of both included and excluded funds cluster around zero (the only exception is for excluded balanced funds for period ending $12 / 07$ where the average gamma was -0.01 ). This implies that fund managers did not exhibit market timing skills overall, though there was more suggestion of market timing ability among equity fund managers compared to balanced fund managers. In addition, the funds on the included list do suggest some additional market timing ability compared to excluded funds: between 27.5-29 percent of the equity funds reported gammas larger than zero (significant at the five percent level), more than the 13.33-22.86 percent reported for excluded funds. In general, however, most fund managers did not exhibit market timing skills.

\section{Performance Persistence by Unit Trust Managers}

Some investors believe they can identify fund managers who are able to outperform the market, so they seek out funds with a consistently good track record. To measure the consistency of fund performance, it is useful to rank the unit trusts and compare rankings across consecutive sample periods. We first compute Jensen's alpha for all unit trusts over a sub-period of 30 months and rank them in decreasing order; then we repeat the process for the next, non-overlapping 30 month sub-period to generate another ranking and compute the Spearman's rank correlation coefficient $(\rho)$ for these two pairs of rankings. Under the null hypothesis of no persistence in performance of unit trusts over time, the two sets of rankings will be uncorrelated and $\rho$ should be close to zero.

Results appear in Table 6, where we see that the rankings are significant at the five percent level in the bull market period ending 12/07, but not for the earlier bear market ending 12/01. Interestingly, there is some persistence for equity funds and the Spearman coefficient for included 
funds is much larger than for excluded funds in the later period where the Spearman coefficients are not significantly different from zero for the earlier period. Therefore, overall, the empirical results on fund manager performance persistence is mixed, though the included equity funds showed more persistence in performance than did the excluded funds.

Table 6 here

\section{Discussion and Conclusions}

Government regulators around the world are striving to shape the financial environment within which often naïve and overwhelmed investors can grow their pension assets (Hinz et al. 2010). Singapore has recognized that many workers may find it daunting to select investment instruments and judge manager performance, so the Provident Fund Board has defined criteria for so-called included funds in an effort to protect investors from underperformance. We show that these criteria have been effective over the two ten-year spans ending in 2001 and 2007, since included funds performed better than excluded funds along several dimensions. Specifically, fund managers earned higher average returns, demonstrated better stock-picking, and displayed better market-timing skills, than their excluded fund counterparts. In addition, the included funds exhibited stronger persistence in performance, though they offered marginally lower diversification benefits to plan participants.

While this is good news, it is also the case that restricting investment portfolios available to participants is likely to be only a partial step toward enhancing workers' financial security. That is, people often make serious investment mistakes even when they are offered extremely efficient investment choices (Tang et al. 2010). As a consequence, it remains essential to enhance fund competitiveness in an effort to drive down costs, and to educate participants 
regarding the importance of saving, interest compounding, and risk/return attributes of their pension investments. 


\section{References}

Brocanto, J. and Chandy, P. (1994). “Does Market Timing Really Work in the Real World?” Journal of Portfolio Management, 20: 39-44.

Carhart, M. (1997). “On Persistence in Mutual Fund Performance.” Journal of Finance, 52, 5782.

Central Provident Fund (CPF 2007). Asset Enhancement: CPF Investment Scheme - How it Works. Central Provident Fund Board. http://mycpf.cpf.gov.sg/Members/GenInfo/FAQ/investment/CPF-Invscheme.htm

Central Provident Fund (CPF, 2010). FAQs on various CPF pension scheme. mycpf.cpf.gov.sg/Members/Gen-Info/FAQ/Investment/INV.htm

Chang, E.C. and W.G. Lewellen. (1984). "Market timing and mutual fund investment performance.” Journal of Business, Vol. 57: 57-72.

Chia, N.C., Chua, S. T. and Tsui, A. K. (2007). "The Central Provident Fund Investment Scheme in Singapore: A Preliminary Comparison of Returns.” Working Paper, National University of Singapore, Department of Economics, July.

Cumby, R.E. and J.D. Glen. (1990). "Evaluating the Performance of International Mutual Funds.” Journal of Finance. 45: 497-521.

Ferson, W.E. and R.W. Schadt. (1996). "Measuring Fund Strategy and Performance in Changing Economic Conditions.” Journal of Finance. 51, No. 2, June: 425-461.

Grinblatt, M. and S. Titman. (1992). "Persistence in Mutual Fund Performance.” Journal of Finance, 47: 1977-1984.

Gruber, M.J. (1996). “Another Puzzle: The Growth in Actively-managed Mutual Funds.” Journal of Finance, 51, No. 3: 783.

Hendricks, D., J. Patel, and R. Zeckhauser. (1993). "Hot Hands in Mutual Funds: Short Run Persistence of Relative Performance, 1974-1988.” Journal of Finance, 48: 93-130.

Henriksson, R.D. (1984). "Market Timing and Mutual Fund Performance: An Empirical Investigation.” Journal of Business. 57: 73-96.

Hinz, R, H. Rudloph, P. Antolin, and J. Yermo, editors. 2010. Evaluating the Financial Performance of Pension Funds. Washington, DC: World Bank.

Investment Management Authority of Singapore. (IMAS; various years). Fund Information Service for CPFIS-Included Unit Trusts \& Investment-Linked Insurance Products. IMAS and Life Insurance Association of Singapore. http://www.fundsingapore.com 
Jensen, M.C. (1968). “The Performance of Mutual Funds in the Period 1945-1964.” Journal of Finance, 23: 389-416.

Koh, B. S., O.S. Mitchell and J.H.Y. Fong. (2010). “Collective Investments for Pension Saving: Lessons from Singapore’s Central Provident Fund Scheme.” Pensions: An International Journal. (15:2): 100-110.

Koh, B., O.S. Mitchell, T. Tanuwidjaja, and J. Fong (2007). “Investment Patterns in Singapore’s CPF Central Provident Fund.” Journal of Pension Economics and Finance, March 7(1): $1-29$.

Kon, S.J. and F.C. Jen. (1979). "The Investment Performance of Mutual Funds: An Empirical Investigation of Timing, Selectivity, and Market Efficiency.” Journal of Business, 52: 263-89.

Lehmann, B.N. and D.M. Modest. (1987). "Mutual Fund Performance Evaluation: A Comparison of Benchmarks and Benchmark Comparisons.” Journal of Finance, 42: 23365.

Low, Linda and T.C. Aw. (1997). Housing a Healthy, Educated, and Wealthy Nation through the CPF. The Institute of Policy Studies. Singapore: Times Academic Press.

Low, Linda and T. C. Aw (2004). Social Insecurity in the New Millennium: The Central Provident Fund. Singapore: Times Academic Press.

Lusardi, A. and O.S. Mitchell. (2007). “Baby Boomer Retirement Security: The Roles of Planning, Financial Literacy, and Housing Wealth.” Journal of Monetary Economics. 54(1) January: 205-224.

Malkiel, B.G. (1995). “Returns from Investing in Equity Mutual Funds 1971 to 1991.” Journal of Finance, 50: 549-572.

Miller, T.W. and N. Gressis. (1980). "Nonstationarity and Evaluation of Mutual Fund Performance.” Journal of Financial and Quantitative Analysis, Vol. 15: 639-54.

Mitchell, O.S., G.R. Mottola, S. P. Utkus and T. Yamaguchi (2007). “The Dynamics of Lifecycle Investing in 401(k) Plans.” Pension Research Council Working Paper. The Wharton School, University of Pennsylvania.

Morningstar Research Private Limited. (2010 ; Morningstar Direct).

Monetary Authority of Singapore. (2007). Singapore Asset Management Industry Survey. Government of Singapore.

Pfleiderer, P, and S. Bhattacharya (1983). “A Note on Performance Evaluation.” Technical Report No. 714, Stanford Univ., Graduate School of Business. 
Sharpe, W. (1966). “Mutual Fund Performance”. Journal of Business 39: 119-138.

Tang, N., O.S. Mitchell, G. Mottola, and S. Utkus. (2011) "The Efficiency of Sponsor and Participant Portfolio Choices in 401(k) Plans.” Journal of Public Economics.

Treynor J.L. and Mazuy K. (1966). “Can Mutual Funds Outguess the Market?” Harvard Business Review, 44: 131-136.

Tse, Y.K. and J.H.H. Chia. (1997). "An Empirical Analysis of Unit Trust Performance in Singapore.” Working Paper, Singapore Management University.

Wagner, J., S. Shellans, and R. Paul. (1992). "Market Timing Works where it Matters Most... In the Real World." Journal of Portfolio Management, 18: 86-90. 
Table 1. Financial Instruments Available for Investment in the CPF Ordinary (OA) and Special Accounts (SA)

\begin{tabular}{|c|c|}
\hline $\begin{array}{l}\text { Ordinary Account } \\
\text { All of OA assets may be invested in: }\end{array}$ & $\begin{array}{l}\text { Special Account } \\
\text { All of SA assets may be invested in: }\end{array}$ \\
\hline $\begin{array}{l}\text { Fixed Deposits } \\
\text { Singapore Government Bonds } \\
\text { Statutory Board Bonds } \\
\text { Bonds Guaranteed by Singapore Government } \\
\text { Annuities } \\
\text { Endowment Insurance Policies } \\
\text { Investment-linked Insurance Products } \\
\text { Unit Trusts } \\
\text { Exchange Traded Funds } \\
\text { Fund Management Accounts }\end{array}$ & $\begin{array}{l}\text { Fixed Deposits } \\
\text { Singapore Government Bonds } \\
\text { Statutory Board Bonds (Secondary Market only) } \\
\text { Bonds Guaranteed by Singapore Government } \\
\text { Annuities } \\
\text { Endowment Insurance Policies } \\
\text { Selected Investment-Linked Insurance Products* } \\
\text { Selected Unit Trusts* } \\
\text { Selected Exchange Traded Funds* }\end{array}$ \\
\hline $\begin{array}{l}\text { Up to } 35 \% \text { of investible assets }{ }^{\#} \text { may be } \\
\text { invested in: } \\
\text { Shares } \\
\text { Property Funds (or real estate investment trusts) } \\
\text { Corporate Bonds }\end{array}$ & \\
\hline $\begin{array}{l}\text { Up to } 10 \% \text { of investible assets }{ }^{\#} \text { may be } \\
\text { invested in: } \\
\text { Gold (currently only UOB offers new gold } \\
\text { investments) }\end{array}$ & \\
\hline
\end{tabular}

Source: CPF (2010)

Notes:

\# Investible assets refer to the net Ordinary Account balance after withdrawals for education and investment.

* Those found in the lowest three tiers of the CPFIS Risk Classification System Table unless otherwise stated. Risk classification tables for unit trusts, investment-linked insurance products, and exchange traded funds are at www.cpf.gov.sg/cpf_info/Benefits/Asset/Assetenh.asp.

1) Annuities, endowment insurance policies, \& investment-linked insurance products must be offered by insurance companies included under CPFIS. Endowment policy maturity dates must not be later than the member's $62^{\text {nd }}$ birthday.

2) Unit trusts and investment-linked insurance products must be managed by Fund Management Companies included under CPFIS. Fund managers are required to invest according to the Investment Guidelines set by CPF Board.

3) Exchange traded funds must meet guidelines set by CPF Board and be listed on the Singapore ExchangeSecurities Trading (SGX-ST).

4) Fund managers of fund management accounts are required to invest according to the Investment Guidelines set by CPF Board.

5) Shares of Companies, Units of Property Funds or Property Trusts and Corporate Bonds (CPFIS-OA only) must be offered by companies incorporated in Singapore. Also, they must be fully paid ordinary or preference shares or corporate bonds listed on the Singapore Exchange-Securities Trading (SGX-ST). 


\section{Table 2. Criteria for Admitting Unit Trusts into the CPF Investment Scheme}

\section{Overall Evaluation Benchmark}

Funds ${ }^{1}$ admitted into CPFIS must be ranked within the top 25 percentile of funds in their global peer group. ${ }^{2}$ The ranking will be based on factors such as the capability of fund managers, the investment philosophy of the fund, its key decision makers, the appropriateness and quality of its research and analysis, its portfolio construction and implementation, and its past performance.

\section{Track Record}

New Funds into the CPFIS should have a track record of good performance for at least 3 years.

\section{Sales Charge}

New Funds admitted into CPFIS must have sales charges not exceeding 3\%.

\section{Expense Ratio}

Admitted funds must have an expense ratio ${ }^{4}$ lower than the median expense ratio of existing CPF-included funds in its risk category. The median expense ratios will be reviewed annually. A sample of the median expense ratio is given in the table below.

\begin{tabular}{|l|c|}
\hline \multicolumn{1}{|c|}{ Risk Classification } & \\
& $\begin{array}{l}\text { Median Expense Ratios (\%) of CPFIS Unit Trusts and } \\
\text { Investment-Linked Insurance Products as at 31 } \\
\text { December 04 [Rounded off to the nearest 0.05] }\end{array}$ \\
\hline Higher risk & 1.95 \\
\hline Medium to High Risk & 1.75 \\
\hline Low to Medium Risk & 1.15 \\
\hline Lower Risk & 0.65 \\
\hline
\end{tabular}

Source: http://mycpf.cpf.gov.sg/Business-Partner/Gen-Info/CPFIS/CPFIS_ApplicFMCS.htm Notes:

${ }^{1}$ Funds refer to unit trusts and investment-linked insurance products under CPFIS.

${ }^{2}$ This refers to comparison of funds of similar asset class/strategy on a world-wide basis.

${ }^{3}$ Risk categories are:

a) Higher risk - Funds that invest in equities.

b) Medium to high risk - Funds that invest in a mixture of equities and bonds.

c) Low to medium risk - Funds that invest in fixed income products or bonds.

d) Lower risk - Funds that invest in money market products.

${ }^{4}$ Expense ratios refer to the operating costs of unit trusts and investment-linked insurance products which include investment management fees expressed as a percentage of the fund's average net assets for a given time period. The expense ratio does not include brokerage costs and various other transaction costs that may also contribute to a fund's total expenses. 


\section{Table 3. Summary Statistics for Singaporean Unit Trusts (10-year Holding Period)}

\begin{tabular}{lll}
\hline Summary Statistics & $\begin{array}{l}\text { Bear Market: Decade } \\
\text { ending 12/01 }\end{array}$ & $\begin{array}{l}\text { Bull Market: Decade } \\
\text { ending 12/07 }\end{array}$ \\
\hline & & \\
CPFIS-included Unit Trust: & 17 & 48 \\
Number of funds & 7.96 & $10.27^{*}$ \\
Average Annual Return (\%) & 3.23 & 2.77 \\
CPF OA (average) annual rate (\%) & 3.73 & 3.02 \\
T-notes/bond Yield annual rate (\%) & & \\
Percentage of funds with: & 88.2 & 97.9 \\
Average return > 0 & 82.4 & 85.4 \\
Average return > 3-months' T-bill rate & 82.4 & 85.4 \\
Average return > CPF rate & 88.2 & 64.6 \\
Average return > Benchmark return & & \\
& & 94 \\
Non-included Unit Trusts: & 16 & 7.32 \\
Number of funds & 6.36 & \\
Average Annual Return (\%) & & 98.9 \\
Percentage of funds with: & 81.3 & 86.2 \\
Average return > 0 & 62.5 & 87.2 \\
Average return > 3-months' T-bill rate & 68.8 & 46.8 \\
Average return > CPF rate & & \\
Average return > Benchmark return & 56.3 & \\
\hline
\end{tabular}

Source: Authors' computations; see text.

* A difference of means test showed that mean return included funds of $10.27 \%$ is significantly larger than $7.32 \%$ of excluded funds at the $1 \%$ significance level. 
Table 4: Return and Risk Profiles of Included and Excluded Unit Trusts (\%)

\begin{tabular}{|c|c|c|c|c|c|c|c|}
\hline \multirow[t]{2}{*}{$\begin{array}{l}\text { Types of unit } \\
\text { trusts }\end{array}$} & \multirow[t]{2}{*}{ Average } & \multicolumn{3}{|c|}{$\begin{array}{l}\text { Bear Market: Decade Ending } \\
12 / 01\end{array}$} & \multicolumn{3}{|c|}{$\begin{array}{l}\text { Bull Market: Decade Ending } \\
12 / 07\end{array}$} \\
\hline & & Equity & Balanced & Income & Equity & Balanced & Income \\
\hline \multirow{4}{*}{$\begin{array}{l}\text { CPFIS- } \\
\text { included Unit } \\
\text { Trusts }\end{array}$} & Return & 8.07 & 9.26 & 6.51 & 11.19 & 7.74 & 3.59 \\
\hline & Excess return & 4.19 & 5.33 & 2.68 & 7.94 & 4.58 & 0.55 \\
\hline & Standard deviation & 22.96 & 25.08 & 4.50 & 23.44 & 15.89 & 2.62 \\
\hline & Beta & 0.88 & 0.78 & N.A. & 0.86 & 0.96 & N.A. \\
\hline \multirow{4}{*}{$\begin{array}{l}\text { Non-included } \\
\text { Unit Trusts }\end{array}$} & Return & 6.40 & $\mathrm{NA}^{*}$ & 5.70 & 8.13 & 6.52 & 4.72 \\
\hline & Excess return & 2.57 & $\mathrm{NA}^{*}$ & 1.91 & 4.97 & 3.45 & 1.69 \\
\hline & Standard deviation & 21.62 & $\mathrm{NA}^{*}$ & 4.09 & 21.46 & 9.04 & 4.73 \\
\hline & Beta & 0.88 & $\mathrm{NA}^{*}$ & N.A. & 0.95 & 0.97 & N.A. \\
\hline
\end{tabular}

Note: * Balanced funds not reported due to lack of sample.

Source: Authors' computations; see text. 
Table 5: R-square, Alphas, and Gammas of Unit Trusts

\begin{tabular}{|c|c|c|c|c|c|}
\hline & & \multicolumn{2}{|c|}{$\begin{array}{c}\text { Bear Market: Decade } \\
\text { Ending 12/01 }\end{array}$} & \multicolumn{2}{|c|}{$\begin{array}{c}\text { Bull Market: Decade } \\
\text { Ending 12/07 }\end{array}$} \\
\hline & & Equity & Balanced & Equity & Balanced \\
\hline \multicolumn{6}{|c|}{ Panel A: Average R-square of regression } \\
\hline CPFIS-included Unit Trusts & R-square & 0.72 & 0.82 & 0.71 & 0.71 \\
\hline Non-included Unit Trusts & R-square & 0.80 & NA & 0.83 & 0.77 \\
\hline \multicolumn{6}{|c|}{ Panel B: Average alpha of unit trusts } \\
\hline CPFIS-included Unit Trusts & $\begin{array}{l}\text { Alpha }(\%) \\
\text { \% where Alpha }>0\end{array}$ & $\begin{array}{l}0.35^{* * * *} \\
14.00\end{array}$ & $\begin{array}{l}0.62 \\
100.00\end{array}$ & $\begin{array}{l}0.32 * * * \\
22.50\end{array}$ & $\begin{array}{l}0.07 \\
0.00\end{array}$ \\
\hline Non-included Unit Trusts & $\begin{array}{l}\text { Alpha (\%) } \\
\text { \% where Alpha }>0\end{array}$ & $\begin{array}{l}0.09 \\
6.67\end{array}$ & $\begin{array}{l}\mathrm{NA}^{* *} \\
\mathrm{NA}^{* *}\end{array}$ & $\begin{array}{l}0.10 \\
11.43\end{array}$ & $\begin{array}{l}-0.01 \\
0.00\end{array}$ \\
\hline \multicolumn{6}{|c|}{ Panel C: Average gamma of unit trusts } \\
\hline CPFIS-included Unit Trusts & $\begin{array}{l}\text { Gamma } \\
\% \text { where Gamma }>0 \\
\text { Gamma } \\
\% \text { where Gamma }>0\end{array}$ & $\begin{array}{l}0.00 \\
29.00 \\
0.00 \\
13.33\end{array}$ & $\begin{array}{l}0.00 \\
0.00 \\
\mathrm{NA}^{* *} \\
\mathrm{NA}^{* *}\end{array}$ & $\begin{array}{l}0.00 \\
27.50 \\
0.00 \\
22.86\end{array}$ & $\begin{array}{l}0.00 \\
50.00 \\
-0.01 \\
0.00\end{array}$ \\
\hline
\end{tabular}

Notes:

* Significant at 5\%.

** Balanced funds not reported due to lack of sample.

*** A difference of means test showed that the average alpha of included funds was larger than that of excluded funds at the $1 \%$ significance level.

Source: Authors’ computations; see text. 
Table 6: Spearman Coefficients ( $\rho$ ) of Unit Trusts Ranking on the Jensen Alpha Measure

\begin{tabular}{|c|c|c|c|c|}
\hline \multirow[t]{2}{*}{ Type of fund } & \multicolumn{2}{|c|}{$\begin{array}{l}\text { Bear Market: Decade Ending } \\
\qquad 12 / 01\end{array}$} & \multicolumn{2}{|c|}{$\begin{array}{l}\text { Bull Market: Decade Ending } \\
\text { 12/07 }\end{array}$} \\
\hline & $\mathbf{P}$ & \# of funds & $\boldsymbol{\rho}$ & \# of funds \\
\hline \multicolumn{5}{|c|}{ CPFIS-included Unit Trusts: } \\
\hline Equity & 0.1716 & 34 & $0.4634^{*}$ & 92 \\
\hline Balanced & 0.8 & 4 & 0.0281 & 19 \\
\hline Income & NA ${ }^{@}$ & 2 & 0.0055 & 13 \\
\hline \multicolumn{5}{|c|}{ Non-included Unit Trusts: } \\
\hline Equity & 0.0365 & 60 & $0.3012 *$ & 164 \\
\hline Balanced & $\mathrm{NA}^{@}$ & 2 & 0.5238 & 8 \\
\hline Income & -0.2308 & 14 & $0.3086 *$ & 48 \\
\hline
\end{tabular}

Notes:

* Significant at 5\% level

@ Statistical significance not computed due to lack of sample.

Source: Authors’ computations; see text. 


\section{Endnotes}

${ }^{1}$ The CPF-included funds can also accept investments from non-CPF monies so these funds' growth is not due entirely to the investment of CPF monies (see MAS 2007).

${ }^{2}$ Morningstar merged with Standard \& Poor's Fund Services Asia in 2007. Standard \& Poor's Fund Services Asia has been appointed by the Singaporean Funds Performance Tracking Committee, a committee chaired by and comprising of representatives from the Investment Management Association of Singapore (IMAS), the Life Insurance Association of Singapore, and the Securities Investors Association (Singapore), to monitor the performance of all unit trusts and ILPs included under the CPFIS. Standard \& Poor’s Fund Services Asia monitors the performance of all unit trusts (UTs) and ILPs included in the CPFIS admissible set of investment options since mid-2002 (IMAS, various years).

${ }^{3}$ There is also a CPF Medisave Account (CPF-MA) returning four percent fixed which we do not focus on here. The CPF-OA rate of 2.5 percent is a floor rate since the actual interest rate paid is the maximum of 2.5 percent or a weighted average of the 12-month fixed deposit rates (80 percent) and the month-end saving rates (20 percent) of major local banks over the preceding three months. Plan participants can therefore expect to earn high default interest rates when market interest rates are trending upwards. As for the CPF-SA rate, it is now pegged to the 12month average yield of the 10-year Singapore Government Security (10YSGS) plus 1 percent (since January 2008). 